\title{
Laparoscopy \& robotics: a historical parallel
}

\section{Laparoscopia \& robótica: um paralelo histórico}

\author{
Miguel Prestes Nacul, TCBC-RS 1 (iD.
}

\section{A B S T R A C T}

The evolution of robotic platforms has brought up ethical, economic, educational, and clinical applicability issues that refer to the early 1990s, when laparoscopy began its dissemination as a technology that would revolutionize surgery. Introduced in Brazil since 1990 , laparoscopy has received a lot of resistance from different sectors, including the medical academy itself. The technique was considered expensive, complex, poorly available and with limited clinical applications. However, in a short time, it was established as the gold standard for the treatment of most diseases in different organ systems and surgical specialties. At this time, similarly to laparoscopy, robotic surgery is expressed as a disruptive technology, determining an important breakdown of paradigms, and moving the wheel of history forward. The author draws a parallel in relation to the use of both technologies in the surgeon's armamentarium. The fear of the "new technology", seen when laparoscopy appeared, is repeated with the advent of robotic surgery. Laparoscopy and robotic surgery, at the same time, imposed new knowledge challenges for surgeons, anesthetists, nurses, engineers - the need to learn again, to develop new skills. The previous experience of implementing laparoscopy should always be remembered and considered, optimizing the current scenario of the robotic platform, in its introduction and dissemination with the surgical community. The advent of the "robotic era" and its evolutionary potential will continue to assist surgeons in their mission to serve their patients with quality and safety.

Keywords: Laparoscopy. Medical History. Robotic Surgical Procedures.

$T_{\text {in }}^{\text {hed }}$ he expanding application of technological advances in medicine has increasingly raised concerns among patients, surgeons, and hospitals about how to introduce them and use them safely and effectively in clinical practice $^{1}$. In surgery, the evolution of the robotic platform represented in the Western world by the Da Vinci robot from the company Intuitive $₫$ has raised several issues for discussion. Ethical, economic, educational, and clinical applicability aspects involving the implementation of robotic surgery in surgical practice take us to the early 1990s, when laparoscopy began to be disseminated as a disruptive technology that would revolutionize surgery ${ }^{2,3}$.

Introduced in Brazil from 1990 on, laparoscopy was seen with great resistance by different sectors, including the medical academy itself $^{3}$. In addition, the technique was considered expensive, complex, poorly available, and with limited clinical applications ${ }^{3}$. Used on an increasing scale by little trained surgeons, it has spread heterogeneously not only in Brazil, but also in the rest of the world. However, in a short time this new technology has become the standard treatment of most diseases in different organ systems and surgical specialties $^{4}$. The technological evolution has led to a significant development in the quality of video-surgical equipment and instruments. Meanwhile, surgeons have evolved technically, relying on more effective training methodologies based on simulation, a fundamental factor for the definitive establishment of laparoscopy ${ }^{4}$.

The first surgical procedures assisted by a robotic tool are also form the 1990s. The robot era in the abdominal surgery begun with the launch by Computer Motion $®$ of the robot Zeus ${ }^{5}$. However, the fusion of Computer Motion $₫$ and Intuitive $₫$ defined the Da Vinci platform as the evolutionary model of robotic surgery ${ }^{5}$. Today, thousands of Da Vinci robots are spread around the world and are increasingly incorporated into the universe of surgery in various specialties ${ }^{5}$. The arrival of new robotic platforms from other companies and the natural evolution of Da Vinci project a robotic, and probably flexible, future.

As laparoscopy in the 1990s, Robotic surgery

1 - Colégio Brasileiro de Cirurgiões, Comissão de Cirurgia Minimamente Invasiva e Robótica - Porto Alegre - RS - Brasil 
currently acts as a disruptive technology, determining an important breakdown of paradigms and moving the wheel of history forward 3,5 . When analyzing the particularities of the introduction of both technologies in the surgeon's armamentarium, we note many similarities. Robotic surgery and laparoscopy act as an interface between surgeon and patient, and complement each other, since it is in the laparoscopy realm (closed cavity, video camera, indirect image, artificial lighting, and pneumoperitoneum) that robotic surgery thrives ${ }^{3,5}$. The equipment involved in laparoscopy, as well as robotic surgery (in much greater quantity and variety), makes the environment inside the operating room more complex and threatening due to the filling of the physical space and the diversity of hardware to be controlled ${ }^{3}$. In this context, a larger and very well-trained surgical team is highly necessary. Communication between members of the surgical team becomes more complicated and relevant, significantly influencing the procedure's success. It is evident that robotic surgery is more demanding in this regard. Both technologies (robotics much more so!) imposed new knowledge challenges for surgeons, anesthesiologists, nurses, and engineers - the need to learn again, to develop new skills $s^{4,5}$.

The advent of laparoscopy and robotic surgery increased the direct costs related to surgical procedures $^{3,5}$. In a few years, laparoscopy was able to prove cost-effectiveness based on the significant decrease in the value of equipment and instruments associated with the decrease in hospital stay and the patients' swift return to professional activities ${ }^{3}$. It is likely that robotic surgery will follow this same path, even if the cost is much higher than that of laparoscopy.

New technologies establish the need for new teaching methodologies ${ }^{4}$. In laparoscopy, the main model was real simulation in simple simulators ("black boxes") and experimental surgery in a live animal model. In robotics, virtual reality simulation seems to be the most accessible and sustainable model ${ }^{6,7}$. Thus, the use of experimental surgery in live animals tends to decrease in robotics. In this sense, the use of parts of human corpses appears as an interesting option, although still expensi$v^{6}$.

Surgical tutoring, initially little used in laparoscopy, is now established as an important method for the development of advanced procedures, such as bariatric and colorectal video-surgery ${ }^{4}$. In robotic surgery, tutoring is a fundamental condition for training and certification ${ }^{6}$. The deficiency in the number and quality of courses hindered the evolution of laparoscopy and is repeated in robotic surgery, causing inadequate training, with excessive influence from the industry ${ }^{6,7}$.

Certification has also been the subject of intense debate since the introduction of laparoscopy in Brazil. Only in the mid-2000s, when the Brazilian Medical Association (AMB) considered laparoscopy as a domain area of general and digestive surgery, and defined criteria for the granting and registration of degrees, that certification became a reality ${ }^{4}$. The certification in robotic surgery has been directed by the industry ${ }^{6}$. Thus, action by the Brazilian College of Surgeons (CBC) in partnership with other specialty societies proposes national regulations for the process of training and certification in robotic surgery in the country ${ }^{6}$.

The similarities that we observed in the process of introduction and development of both technologies did not show great differences. Laparoscopy was an evolution of the old laparoscopy, described at the beginning of the $20^{\text {th }}$ century, through the incorporation over time of technological advances, such as fiber optics, electrosurgery, $\mathrm{CO}_{2}$ insufflators, video cameras, etc ${ }^{2}$. In fact, when comparing equipment and instruments, laparoscopy seems an outdated technology in relation to robotic surgery. The robotic platform has extraordinary potential for incorporating other technologies, especially in information $^{5}$. In addition, robotic surgery approaches open surgery in terms of movements and vision, with greater freedom of action of the articulated forceps and the possibility of third-dimensional imaging, even though the Da Vinci platform does not provide haptic feedback ${ }^{5}$.

Recent improvements in telemedicine, with the use of high-speed wi-fi connections, provide for an increasing use of distance training and tutoring of surgeons and, soon, telesurgery assisted by robotic tools ${ }^{8}$.

Between analogies and parallels, we can conclude that the fear of "new technology", seen during the appearance of laparoscopy, is repeated with the advent of robotic surgery, expressed by overly conservative surgeons and by uninformed patients. Questions from 30 years ago are repeated without embarrassment. The 
previous experience of implementing laparoscopy should be remembered and considered, optimizing the current scenario of the robotic platform in the introduction and dissemination to the surgical community and the provi- sion of benefits to patients. The advent of the "robotic era" and the evolutionary potential will continue to assist surgeons in their mission to serve their patients with quality and safety.

\title{
R E S U M O
}

\begin{abstract}
A evolução das plataformas robóticas tem trazido à discussão questões éticas, econômicas, educacionais e de aplicabilidade clínica que remetem ao início dos anos 1990, quando a videolaparoscopia iniciava a sua disseminação como tecnologia que revolucionaria a cirurgia. Introduzida no Brasil a partir de 1990, a videolaparoscopia recebeu muita resistência por parte de diferentes setores, incluindo a própria academia médica. A técnica foi considerada muito cara, complexa, pouco disponível e com aplicações clínicas limitadas. No entanto, em pouco tempo, se estabeleceu como padrão-ouro para o tratamento de grande parte das doenças em diferentes sistemas orgânicos e especialidades cirúrgicas. Neste momento, de forma semelhante à videolaparoscopia, a cirurgia robótica se expressa como tecnologia disruptiva, determinando importante quebra de paradigmas e movendo adiante a roda da história. O autor traça um paralelo em relação a utilização de ambas tecnologias no armamentário dos cirurgiões. O medo da "nova tecnologia", visto quando do aparecimento da videolaparoscopia, se repete com o advento da cirurgia robótica. Videolaparoscopia e cirurgia robótica, ao seu tempo, impuseram novos desafios de conhecimento para cirurgiões, anestesistas, enfermeiros, engenheiros - necessidade de aprender de novo, desenvolver novas habilidades. A experiencia pregressa da implantação da videolaparoscopia deve ser sempre lembrada e considerada, otimizando o cenário atual da plataforma robótica, na sua introdução e disseminação junto à comunidade cirúrgica. O advento da "era robótica" e seu potencial evolutivo continuarão a auxiliar os cirurgiões em sua missão de atender com qualidade e segurança seus pacientes.
\end{abstract}

Palavras chave: Laparoscopia. História da Medicina. Procedimentos Cirúrgicos Robóticos.

\section{REFERENCES}

1. Pradarelli JC, Havens JM, Smink DS. Facilitating the Safe Diffusion of Surgical Innovations. Ann Surg. 2019;269(4):610-1.

2. Lau WY, Leow CK, Li AK. History of endoscopic and laparoscopic surgery. World J Surg. 1997;21(4):444-53.

3. Cezário Melo MA. Mudanças: conceitos e resistências. In: Melo $M C$, editor. A reconfiguração da cirurgia. Recife, PE: Editora Prazer de Ler - Distribuidora de Edições Pedagógicas Ltda; 2010. p. 21-39.

4. Nácul MP, Cavazzola LT, de Melo MC. Current status of residency training in laparoscopic surgery in Brazil: a critical review. Arq Bras Cir Dig. 2015;28(1):81-5.

5. Leal Ghezzi T, Campos Corleta O. 30

Received in: 26/08/2020

Accepted for publication: 16/09/2020

Conflict of interest: no.

Funding source: none.
Years of Robotic Surgery. World J Surg. 2016;40(10):2550-7.

6. Nacul MP, Melani AGF, Zilberstein B, Benevenuto DS, Cavazzola LT, Araujo RLC, Sallum RAA, Aguiar-Jr S, Tomasich F. Educational note: teaching and training in robotic surgery. An opinion of the Minimally Invasive and Robotic Surgery Committee of the Brazilian College of Surgeons. Rev Col Bras Cir. 2020;47:e20202681.

7. Stefanidis D, Fanelli RD, Price R, Richardson W; SAGES Guidelines Committee. SAGES guidelines for the introduction of new technology and techniques. Surg Endosc. 2014;28(8):2257-71.

8. Wood D. No surgeon should operate alone: how telementoring could change operations. Telemed J E Health. 2011;17(3):150-2.

\section{Mailing address:}

Miguel Prestes Nacul

E-mail: miguelnacul@gmail.com 